\title{
Shore Morphology and Sediment Characteristics South of Pangani River, Coastal Tanzania
}

Y.W. Shaghude,

University of Dar es Salaam, Institute of Marine Sciences, P.O. Box 668, ZANZIBAR

Email: shaghude@ims.udsm.ac.tz

\section{ABSTRACT}

The shore morphology and nearshore sediments between the Pangani and Kipumbwi rivers were investigated to describe the shore and the reef platform sediments characteristics and also to update information on recent shoreline changes along the Tanzania mainland coast. The information gathered during this study comes from field observations, sediment sampling of the area and interviews with Pangani residents. The investigated area is a patch reef coast with narrow or no beaches and fossil reef terrace islands offshore, Pangani bay and estuary are among the most prominent shore features. Historical information indicates that, both the bay, and the estuary have undergone significant changes during the last 60 years. While the growth of the estuary has mainly been influenced by the reduced fresh water discharges, the bay has been mainly influenced by shore erosion induced by the high wave activity. The distribution of sediments on the sea bottom is mainly controlled by bathymetry, with sand (medium to coarse) dominating water depths less than $10 \mathrm{~m}$ and silt dominating depth greater than $15 \mathrm{~m}$. Sediments in water between 10 and $15 \mathrm{~m}$ depth are dominated by fine sand/silt. The carbonate production in the investigated area is limited by the high influx of siliciclastic sediments from the Pangani, Kipumbwi and Ushongo Mabaoni depo-centres. While previous studies attribute the disappearance of Maziwi island to sea level rise, the present study considers the anthropogenic influence to be the major causative factor. Sea level is also considered to be one of the potential threats to the preservation of small islands such as the Maziwi, However, the present study believes that if indeed the vegetation on the island has been cleared as is reported, this action has hastened its disappearance. 


\section{INTRODUCTION}

Information concerning shore morphology and nearshore sediment characteristics in coastal Tanzania is scanty. Although the work of Alexander (1966) provide some basic information on the major characteristics of the shore of the Tanzania mainland north of Dar es Salaam, detailed information on the shore morphology is lacking as the shore mapping was conducted at small scale. Guidelines for the study of shoreline changes in the Eastern African Region has recommended detailed study on shore morphology, which include also updating of existing old information (Kuria and Nyandwi, 2000).

Studies which describe aspects of coastal sediment in Tanzania include: Kaaya (1985), Fay et al (1992), Ngusaru (1995), Muzuka (2001), Muzuka and Shaghude (2000) and Shaghude and Wannäs (1998, 2000). The studies of Kaaya (1985) and Ngusaru (1995) deals with backshore sediments of the Dar es Salaam area and their main focus was on the palaeodepositional environments of these sediments. The studies of Fay et al (1992), Muzuka (2001) and Muzuka and Shaghude (2000) were conducted at Msasani Bay, north of Dar es Salaam harbour and their focus was on grain size distribution, carbonate and organic matter content. The other studies of Shaghude and Wannäs (1998, 2000) provides some general description of Zanzibar channel sediments in terms of grain size distribution, carbonate content, biogenic and mineralogical composition.

In the Eastern African Region, there is an increasing need to establish a coastal resource database. In the case of Tanzania, although a great deal of effort has been made to document the information on the living resources such as mangroves, coral reefs, sea grass beds, fish and other marine fauna, limited information exists on the non-living resources. The coast of Tanzania is fed by sediments from large rivers such as Rufiji and Ruvuma in the south, and rivers of intermediate size such as Ruvu, Wami and Pangani in the central and northern Tanzania (Fig.1). The coast is therefore potentially rich in offshore aggregate resources, but the offshore extent of this resource is not clearly known. Carbonate sands, eroded from various coral platforms or produced by the 
organisms living within the coral ecosystems exist offshore (Shaghude, 2001), but apart from the Zanzibar channel, which has been investigated by Shaghude (2001) to provide information on the areal extent of such deposits, very little information exist on such sands at other parts of Tanzania.

The major objective of the present study is to collect appropriate baseline information needed to update the Tanzania's coastal resource database on non-living resources. The other objective of the study is investigate the shore morphology and associated recent shoreline changes along the coast of Tanzania south of Pangani river.

\section{MATERIALS AND METHODS}

\section{Study site}

The present investigations were conducted on the Tanzania mainland coastal section between the Pangani and Kipumbwi rivers. The coastal section is approximately $40 \mathrm{~km}$ long (Fig. 1). The shore characteristics of the investigated area have been described by Alexander (1966, 1968, 1969, 1985). According to Alexander (1966) the foreshore along this section of the Tanzania mainland coast has a narrow beach with moderate to steep gradient (1/15 to $1 / 30)$ and a nearly flat outer platform (1/200) that ranges from $70 \mathrm{~m}$ to over 350 to $550 \mathrm{~m}$ wide, the latter width occurring off the mouths of streams. The foreshore sediments are sandy except for occasional extensive patches of exposed beach rock along the beach.

Fault traverse the Tanzanian coastal area and play a role in shaping its present geomorphological form (Stockley 1928; Kent et al., 1971; Shaghude and Wannas, 2000). Pleistocene and Recent faults divided the coastal plateau into three terraces. The investigated area is part of the lowest, Mtoni terrace (Alexander, 1968). Beach ridge systems are also common along many parts of coastal Tanzania, and are indicative of Pleistocene/Holocene sea level changes (Alexander, 1969; Muzuka et al, 2002). The ridges of the investigated area are elevated some decimetres to a few metres above spring tide level, suggesting that they formed either due a 
fall of global sea level from a highstand of 1-3 m above its present position, or as a result of late Holocene uplifting of the Mtoni terrace (Alexander, 1969, Fay et al, 1992).

The weather is across the area warm and moist, with sea surface temperature varying between 25 and $30{ }^{\circ} \mathrm{C}$, and annual rainfall exceeding $1000 \mathrm{~mm}$. Studies conducted further south of the investigated area show that both sedimentological and oceanographic phenomena are influenced by the monsoon winds (e.g. Lwiza, 1994; Muzuka and Shaghude, 2000; Nyandwi, 2001). During the north-east monsoon the wind generated waves approach the coast from the northerly sector and produce longshore currents with a southerly component. During the southeast monsoon the wind direction is reversed and so is the wave climate. The speed of the alongshore currents is at a minimum during the north-east monsoon (November to March) and a maximum during the south-east monsoon (May to September). As a result of seasonal variability in wave and current climate the erosion/accretion of the coastal section north of Dar es Salaam is also cyclical in pattern and intensity, but the net longshore transport is northward.

\section{Data collection and treatment}

The field work for this study was conducted in October 2002 and July 2003. It consisted of foreshore mapping beach sediment sampling, offshore bottom sediment sampling and gathering relevant historical information. Beach sediment samples were collected along the middle of the beach slopes using a small shovel where approximately $2 \mathrm{~cm}$ of surface sediment was scooped to give about $1 \mathrm{~kg}$ of sample. The shore features were simultaneously observed and documented while collecting the beach samples.

Historical information concerning the recent disappearance of Maziwi island and the present shoreline changes in the vicinity of Pangani river mouth was gathered by interviewing Pangani residents. The offshore bottom sediment samples were collected using a light (approximately $10 \mathrm{~kg}$ ) Van Veen grab sampler that collected at least $1 \mathrm{~kg}$ of sediment material. Altogether there were 100 sediment samples collected. The sample locations were taken using a 
hand GPS and the water depths of the offshore samples were measured using a hand echo sounder. The water depth was subsequently tidally corrected.

All the sediment samples were washed with fresh water to remove salts and then dried in the oven at $50{ }^{0} \mathrm{C}$. Samples with significant proportion of sand (54 samples) were subjected to dry sieving to determine the grain size distribution. Sieving for these samples was done using a set of 12 sieves, ranging from -1 phi ( $2 \mathrm{~mm}$ ) to 4 phi (63 microns) spaced at $1 \frac{1}{2}$ phi intervals. Carbonate content in the samples $\left(\% \mathrm{CaCO}^{3}\right)$ was determined by acid leaching method, where dilute $\mathrm{HCl}$ (25\%) was used to leach approximately 3 to $5 \mathrm{~g}$ of a sub-sample. Leaching was run in duplicates for 10 samples out of the 77 samples, which were analysed by this technique, and reproducibility was considered to be satisfactory (relative difference was less than $2 \%$ ).

\section{RESULTS}

\section{Shore characteristics and sea level changes}

Close to the river mouths the beach slope was relatively steeper $\left(>50^{\circ}\right)$ with very coarse sediments and going further away from the river mouths the beach slope in most cases were gentle $\left(<30^{\circ}\right)$ with fine to medium sand and sand ripples. Most of the ripple wavelengths were between $30-50 \mathrm{~cm}$ and heights about $3 \mathrm{~cm}$. Bioturbation caused by living organisms were structures were common on the tidal flats

Using the standardized coastal classification developed by Kuria and Nyandwi (2000) the section of the coast between Pangani Bay and the Kipumbwi river mouth may be described as a patch reef coast, with fossil reef terrace /islands (Fig. 2), and narrow or no beaches. With the exception of the shore section on the immediate south of Pangani Bay (Pangani Bay to Pembe Yabwe) which is cliffed (Fig. 2-a) with no sand beach, the remaining part of the shore may be described as a non-cliffed coast (Fig. 2-b) characterized by a Holocene shore with narrow sandy beaches. Wave-cut terraces are common along the cliffed section of the shore, indicating high wave activity. Morphologically, the non-cliffed section of the shore from Pembe Yabwe to Sange 
forms about three macro-bays. In comparison to the northern shore section of the investigated area this part of the shore is relatively protected from wave erosion. In some parts (e.g. at Kipumbwi) significant recent shoreline accretion is evident from mangrove colonization of the foreshore, and the current shoreline is about 100 - 150 m seaward from old shoreline.

The River Pangani is considered to be the largest supplier of siliciclastic sediments to the sea. At its entrance to the sea, Pangani Bay and estuary are the most prominent shore features. The present study has identified significant growth of the bay and evolution of the estuary during the last 50-60 years. The growth of the bay, which has taken place at the expense of shore erosion on the immediate north of the river mouth is currently posing a considerable threat to the Pangadeco Hotel, which was formerly located more than one km from the shoreline.

People at Pangani, indicated that the current erosion on the northern side of the river mouth is a recent phenomena. Most of them associate the current erosion with the increase in the water level in the vicinity of the river mouth. "Mzee Kinyasi (a 70 year oldman)” revealed that during his school dayage, there were regular canoes ferrying students to and from Bweni village (located on the southern bank), for their daily attendance to a primary school in Pangani Town on the northern bank. Students who could not afford the fare opted to use a foot passage (which was normally dry during low tide), which existed south of the canoe route (Fig.3). Today it is impossible to cross the river by foot at this location under any tidal condition. The old man further revealed that during 1960's the present Pangadeco Hotel was about $1 \mathrm{~km}$ from the shoreline and the area between the present shoreline and the old shoreline was covered by mangroves and casuarinas trees, suggesting that the shore has been retreating at the rate of at least $20 \mathrm{~m}$ per year.

Another petty trader who migrated to Pangani 4 years ago reported that coconut tax averters used a passage through the beach in front of the Pangadeco Hotel to transport their coconut (using trucks) to Tanga. Efforts were made to block the illegal passage using tyre fencing which were erected at the edge of the shore. During the present study, the petty trader showed me the approximate location where the tyres used to be as they are no longer observable in place. All 
the tyres are reported to be submerged beneath the sand as a result of the continued erosion of the shore. The estimated shore retreat during the 4 years period is about $30 \mathrm{~m}$ (Plate 1), which gives an annual rate of about $7.5 \mathrm{~m}$

The salinity intrusion upstream is also reported to have increased significantly during the last 50-60 years. The old man revealed that during his school days age crocodiles were common as far down stream as Kimu. Today, the crocodiles have been forced to move further upstream to Kumba Mtoni (Fig. 3) as they cannot tolerate the changing brackish water conditions. It appears therefore that significant saline intrusion into the Pangani river estuary has taken place during the last 50-60 years.

Three fishermen, one news reporter and one old man (Mzee Kinyasi) were separately interviewed to collect information regarding the history of Maziwi island (Fig. 1) and its recent disappearance. All revealed that up to at least 1960's the island used to be exposed above the water at all tide conditions, and it was covered with many casuarinas trees. The island at this time also several times larger than at its present size.

All the interviewed people associate the disappearance of the island with the war between Tanzania and Uganda (1978-1980). It is reported that during the war all the trees in the island were deliberately cleared for fear that the enemy's troops might use the island as a base and a hiding place. The interviewed oldman reported that another island, Buyuni Mdogo (also locally known as "Msitu wa Mkwaja”), located further south of the present investigated area suffered a similar fate. Both islands used to be temporary homes for fishermen, where fishermen could stay for about 2 to 3 days, and they also provided nestling grounds for turtiles.

Two other important estuarine/macro-delta systems in the investigated area are found at Kipumbwi and Ushongo Mabaoni. The two deltas supply significant volumes of siliciclastic sediments to the sea. Of the two, Kipumbwi, which receives most of its siliciclastic sediments and fresh water via the Msangasi river is the larger. As for the later delta, most of the fresh water and siliciclastic supply is through seasonal streams, which are generally dry during dry season. 
Sand spits and mangrove stands occur as the most prominent foreshore features at both estuaries. Another less important macro-delta is Ushongo Mtoni (Fig. 1).

Offshore fossil reef platforms namely, the remnants of the former Maziwi island, Ushongo and Datcha sand banks and Kipumbwe reefs are prominent features. All these reef platforms are currently submerged during high tides, and all are located within 7 to $10 \mathrm{~km}$ of the shoreline.

\section{Sea bottom morphology}

The sea bottom morphology between the mainland and the fossil reef platforms (Fig. 4-a) is characterized by more or less gradual increase of water depth from shore to offshore to a maximum depth which is slightly deeper than $25 \mathrm{~m}$. From this maximum depth the bathymetry again decreases gradually towards the fossil platforms. Figure 2a shows the approximate location of the 200 m contour referred from the Admiralty Chart (Chart No 61200). In the southern parts of the investigated area the continental shelf progressively gets wider due to the presence of the Zanzibar Island located about $4 \mathrm{~km}$ south of the Kipumbwi. river and about $40 \mathrm{~km}$ off the mainland coastline

\section{Sediment characteristics}

The nearshore surface sediments are dominated by sediments of siliciclastic origin (Fig. 4b). Using the $50 \%$ contour as the dividing line between the siliciclastic sediments and carbonate sediments, Fig. 4-b shows that siliciclastic sediments occupy a coastal strip about 6-8 Km wide adjacent to the mainland. The carbonate sediments occupy a relatively narrow strip $(1-2 \mathrm{~km}$ wide) adjacent to the reef platforms.

The distribution of Mean grain size sea bed sediments is presented in the map of Fig. 5. The two maps (Fig. 5a-b) show that the sediment grain size is controlled by the bathymetry. Close to the shore and at shallow depths (depth less than $10 \mathrm{~m}$ ), the surface sediments is dominantly sand (Mean grain size < 2.0 phi). Going further offshore the surface sediments is dominantly silt. 


\section{DISCUSSION AND CONCLUSION}

\section{Physical settings of the reef platform sediments}

The presented results reveal some major difference in the energy regime between the northern and southern coastal sections of the investigated area. The major difference is attributed to the difference in sea bottom morphology (or width of the continental shelf) between the areas. Due to the presence of Zanzibar island the continental shelf in the south is relatively wider and the open ocean waves breaks relatively far from the shore. In the north the continental shelf is narrower and consequently the open ocean waves breaks relatively close to the shore.

The hydrodynamic settings of the reef platform sediments of the area is markedly different from the hydrodynamic settings of the Tidal Dominated reef Platform Sediments (TDPRS) west of Zanzibar channel (Shaghude et al., 2002) as well as the Reef platform sediments at Kunduchi area north of Dar es Salaam harbour (Shaghude et al., 2003). The supply of siliciclastic sediments is higher in this investigated area than in west of the Zanzibar channel and at Kunduchi. Due to the high supply of siliciclastic sediments (caused by the presence of large rivers such as the Pangani and Msangasi), the siliciclastic/carbonate transition is wider than in the two areas cited above. The siliciclastic coastal strip in the present investigated study area is approximately 5 to 8 $\mathrm{km}$ wide, whereas the siliciclastic coastal strip in the other cited study areas is less than $3 \mathrm{~km}$ wide (Fay et al, 1992, Shaghude and Wannäs, 1998; Shaghude, 2001). The low siliciclastic input in the TDRPS west of the Zanzibar channel was attributed to the absence of high relief features on the Zanzibar island and the limited siliciclastic source rocks (Shaghude, 2001). The low siliciclastic input in the Kunduchi sediments was attributed to the absence of major rivers (Fay et al., 1992).

Shallow water marine environments are recognized globally as potential areas for extensive carbonate production due to their primary productivity (Shaghude, 2001). Although such environments are potential sites for extensive carbonate production and accumulation, the 
production is greatly influenced by siliciclastic input to the depositional basin. Shallow marine environments which have low siliciclastic influx from rivers are generally considered to be potentially more important sites for carbonate production and accumulation than shallow marine environments which have high siliciclastic influx from rivers (Nelson and Bornhold, 1983; Carey et al., 1995; Shaghude, 2001).

Increased sedimentation from rivers affects the seawater quality, with detrimental effect to the healthy of most of the carbonate producers. For instance in coral ecosystems, siltation blocks the feeding apparatus of the coral polyps and also reduce the light, which is required by the microscopic algae growing symbiotically within the tissue of coral polyps (Wagner, 1999). Increased sedimentation also effectively limits the extent of the carbonate basin. The extent of siliciclastic influence on the marine carbonate depositional basin depends on the total amount of siliciclastic sediments being discharged. And this depends on the size of the drainage basin and the geomorphic and tectonic characteristics of the basin (Milliman and Meade, 1983; Milliman and Syvitski, 1992; Milliman, 1995; Harris et al., 1996; Robertson et al., 1998). In the present investigated area, the high influx of siliciclastic sediments from the mentioned rivers is considered to be the major limiting factor for the carbonate production and its accumulation.

\section{Recent shoreline changes, coastal erosion problems and salinity intrusion}

The present field investigation noted that while coastal erosion is a threat in the vicinity of the Pangani river mouth, the threat is minimal further south of Pangani. Coastal erosion in Tanzania has been recognized to be a serious problem (BEMC, 1987; Shaghude et al., 1994; Mohammed and Betlem, 1996; Nyandwi, 2001). In the cited studies, the causative factors for the coastal erosion are generally site specific, ranging from both natural causes (wave activity, tides, longshore currents, sea level rise, tectonic processes) to local human actions (removal of coastal natural vegetations such as mangroves, sand and gravel mining along streams which drains the 
beaches, sand and gravel mining on the beaches, destruction of offshore barriers such as coral reefs).

The present study observed that the rate of coastline retreat to the north of the Pangani river mouth is locally between 7 - $20 \mathrm{~m}$ /year. Significant shoreline retreat on the immediate north of Pangani river mouth is also evident from aerial photographs (Makota, TCMP; personal communication). High wave activity in the vicinity of Pangani is considered to be one of the major causative factor for the observed coastal erosion at the immediate north of the Pangani river mouth. The wave erosion may be exacerbated by upstream activities such as damming which may trap significant amount of sediments and reduce the natural sediment flux to the beach.

Waves exceeding $2 \mathrm{~m}$ are common especially during high tides. During extreme tide conditions (e.g. high spring tides) the waves may exceed $3 \mathrm{~m}$ in height. The high wave activity in this coastal section has been attributed to the narrow nature of the continental shelf, which forces the large open shelf waves to break close to the shore. Further, the coastal section lacks a continuous reef structure, which could protect the shore during normal tide conditions. The whole coastal section in the vicinity of Pangani river mouth is exposed to strong wave action, but the coastal section just south of Pangani is composed of reef limestones. Wave undercut beach terraces are the dominant features of this coastal section, indicative of an eroding shoreline. However because of the rocky nature of the coast, the shore is retreating slowly. The coastal section on the immediate north of the river mouth is composed of loose sand material. Consequently, the shore is retreating relatively faster.

The Nyumba ya Mungu dam, with storage capacity of 875 million $\mathrm{m}^{3}$ (Kitova, 2001) and commissioned in 1968 is located $75 \mathrm{~km}$ south of Mt. Kilimanjaro (one of the major water and sediment contributor to the Pangani river). The dam is a reservoir for the power plant at Nyumba ya Mungu (8 MW) and other power plants further downstream; namely Hale (21 MW), Old Pangani (15 MW) and New Pangani (66 MW). Although historical data for the sediment flux for the river before damming activities are not available, recent studies indicate that potential soil 
erosion in the basin upstream of Nyumba ya Mungu is quite significant. The potential soil erosion upstream of Nyumba ya Mungu has been estimated at 24/ha/yr and, sediment deposition rate into the reservoir stands at 13t/ha/yr (Ndamba, 2002), suggesting that at least 50\% of the sediments eroded upstream of the dam is trapped in the dam. The accelerated beach erosion at Pangani could therefore be related with the upstream damming of the river.

The present study found an evidence of significant increase of salinity intrusion at the Pangani river over the last 60 years. The observed increase in the salinity intrusion along the estuary could possibly be associated with reduced fresh water discharge from Pangani. The water in the Pangani and its smaller tributaries is increasingly being abstracted for irrigation, domestic, small-scale industry and hydropower plants (Huggins, 2000; Kitova, 2001). Although there are no statistical data for the quantification of the extent of water abstraction, several studies report that water scarcity in the Pangani Basin is currently becoming a big issue (e.g. World Bank, 1997; Maganga et al., 2001; Ruwe et al., 2003). Irrigated agriculture is currently considered to constitute the highest proportion of water abstraction of the Pangani (Kitova, 2001). A total of 29,000 ha are under irrigation schemes, ranging from big irrigation schemes (of several thousand ha) and traditional irrigation schemes of few ha. The irrigation efficiency in most of the irrigation schemes is reported to be as low as $30 \%$, suggesting that most of the water is lost before reaching to the farm fields. Due to the increasing demographic changes, the demand for domestic water is also reported to be high. The study of Maganga et al (2001) reports that due to the existing water scarcity, water levels in storage reservoirs are low, and competition for water between different sectors (e.g. farmers and hydropower generators) and between groups of the same sector (e.g. different groups of farmers) has intensified. It is therefore reasonable to associate the observed increase in salinity intrusion with the discussed water scarcity in the Pangani basin.

The presented history of Maziwi Island and its recent disappearance agree with the earlier history presented by Fay (1992). Both studies report that the disappearance of the island occurred during the late 1970's. There is however some conflict on the cause of its recent disappearance. 
Fay (1992) attributes the disappearance of the island to sea level rise, however, the present study considers the anthropogenic influence to be the major causative factor. Sea level is considered to be one of the potential threats to the preservation of small islands such as the Maziwi. However, the present study believes that if the vegetation on the island was cleared as reported, the action hastened its disappearance. The island would have existed longer if the trees had not been cut down.

\section{ACKNOWLEDGEMENTS}

The Western Indian Ocean Marine Science Association (WIOMSA) is gratefully acknowledged for granting the research funds for this study. I am also thankful to the interviewed Pangani residents (namely, Mzee Kinyasi, Mr Semnkande, Mr. Sanga, Hussein and Jumbe) who provided the presented historical information. The positive comments offered by Dr. Muzuka of IMS and the reviewers of this manuscript after submission to WIOMSA are gratefully acknowledged. Finally, I wish to thank Mwadini and Dotto for assisting in sieving and carbonate analyses, respectively. Finally, the author wish to thank the comments received from the reviewer.

\section{REFERENCES}

Alexander, C.S. 1966. A method of descriptive shore classification and mapping as applied to the Northeast coast of Tanganyika. Association of American Geographers Annals, 57:133-154.

Alexander, C.S. 1968. The marine terraces of the north east coast of Tanganyika. Zeitschrift fur Geomorphologie, Supplementband 7:133-154.

Alexander, C.S. 1969. Beach ridges in north-eastern Tanzania. Geographical Review. New York, 59, 104-122.

Alexander, C.S. 1985. Tanzania, In Bird, E.C.F and Schwartz, M.L (editors), The world's coastlines. Van nostrand Reinhold Company Inc., pp691-695. 
[BEMC] Beach erosion monitoring committee, 1987, Beach erosion along Kunduchi beach, north of Dar es Salaam. Report for the National Environment Management Council, 56 p.

Carey, J.S. Moslow, T.F. and Barrie, J.V. 1995. Origin and distribution of Holocene temperate carbonates, Hecarte Strait, Western Canada continental shelf. Journal of Sedimentary Research, A65(1): 185-194.

Fay, M., Muzuka, A.N.N. and Masalu, D.C.P. 1992. Siliciclastic-carbonate transition in surface sediments of a back-reef lagoon north of Dar es Salaam, Tanzania. Sedimentary Geology, 78: 49-57.

Harris, P.T., Davies, P.J. and Marshal, J.F. 1990. Late Quaternary sedimentation on the Great Barrier Reef continental shelf and slope east of Townsville, Australia. Marine Geology, 94: $55-77$.

Huggins, C. 2000. Rural water tenure in East Africa, a comparative study of legal regimes and community response to changing water tenure patterns in Tanzania and Kenya, Final draft May 2000. African Centre for Technological Studies, Nairobi Kenya (ACTS).

Kaaya, C.Z. 1985. The Quaternary stratigraphy, tectonics and sea level fluctuations in the northern Dar es salaam area. MSc. Thesis, University of Dar es Salaam, Tanzania, 125p.

Kairu, K. and Nyandwi, N. 2000. Guidelines for the study of shoreline change in the western Indian Ocean Region. IOC Manuals and Guides No 40, UNESCO 2000, 55p.

Kent, P.E., Hunt, J.A. \& Johnstone, D.W. 1971. The Geology and Geophysics of Coastal Tanzania, 101 p., Geophysical 6, HMS Stationary Office London: Institute of Geophysical Sciences.

Kitova, H.H. 2001. Presentation paper on the development and management of hydropower resources in Tanzania. $\mathrm{H}$ \& E Course at ICH Trondheim Norway, as available at http://www.ich.no/kuns/he2003/paper-Tanzania-new2.pdf.

Lwiza, K.M.M. 1994. Beach erosion north of Dar es Salaam. Proceedings of the IOC-UNEPWMO-SAREC Workshop on an integrated approach to Coastal Erosion, Sea Level 
Changes and their impact. Intergovernmental Oceanographic Commission, Workshop Report No. 96, Supplement 1: 107-111.

Maganga, F.P., Butterworth, J.A. and Moriarty, P. 2001. Domestic water supply, competition for water resources abd IWRM in Tanzania: A review and discussion paper. $2^{\text {nd }}$ WARFA/Waternet Symposium: Integrated Water Resource Management: Theory, Practice, Cases; Cape Town, 30-31 Oct. 2001.

Milliman, J.D. 1995. Sediment discharge to the ocean from small mountainous rivers: The New Guinea example. Geo-Marine Letters, 15: 127-133.

Milliman, J.D. and Meade, R.H. 1983. World-wide delivery of river sediments to the ocean. Journal of Geology, 91: 1-21.

Milliman, J.D. and Syvitski, J.P.M. 1992. Geomorphic/tectonic control of sediment discharge to the ocean: the importance of small mountainous rivers. Journal of Geology, 100: 525-544.

Mohammed, .K. and Betlem, J.1996. Proceedings of the National workshop on coastal erosion Zanzibar, 11-12 April 1996. Zanzibar environmental study series No. 20.

Muzuka, A.N.N. (2001). Sources of organic matter in the Msasani bay and Dar es Salaam harbour. In Marine science development in Tanzania and eastern Africa, edited by M.D. Richmond and J. Francis (Institute of Marine Sciences , University of Dar es Salaam and WIOMSA), pp. 51-60.

Muzuka, A.N.N., and Shaghude, Y.W. (2000). Grain size distribution along the Msasani beach, north of Dar es Salaam harbour. Journal of African Earth Sciences, 30(2): 417-426.

Muzuka, A.N.N. Nyandwi, and Shaghude, Y.W. 2002 Preliminary investigations on the Pleistocene/Holocene sea level changes along the coastline of Tanzania with reference Unguja and Pemba islands. Presented during the International Union of Quaternary Research (INQUA) Conference, 3-8 November, 2002, Maputo, Mozambique.

Ndamba, P.M. 2002. Estimation of soil erosion in the Pangani basin upstream of Nyumba ya Mungu Reservoir, Water Resources Engineering Management (WREM) at UDSM as 
available at http://www.wrem.udsm.ac.tz/publications/ndomba.htm.

Nelson, C.S. and Bornhold, B.D. 1983. Temperate skeletal carbonate sediments on Scott shelf, Northwestern Vancouver Island, Canada. Marine Geology, 52: 241-266.

Ngusaru, A.S. 1995. Grain size analysis and facies interpretation of backshore sediments along the beach area north of Dar es Salaam, Tanzania. Indian Journal of Marine Sciences, 24, 87-90.

Nyandwi, N. 2001. Survey of extent of human-induced beach erosion problems in Tanzania. In Marine science development in Tanzania and eastern Africa, edited by M.D. Richmond and J. Francis, pp. 121-129. WIOMSA Book series No. 1, Regal Press Kenya Ltd.

Robertson, A.I., Dixon, P. and Alongi, D.M. 1998. The influence of fluvial dischargeon pelagic productionin the Gulf of Papua, Northern Coral Sea. Estuarine Coast and Shelf Science, 46: 319-331.

Ruwe, R.K., Kulmiye, A.J., Osore. M.K.W., Obura, D., Otiato, P.S., Mutoro, D., Shunula, J.P., Mwanguni, S. and Misana, S. 2003. Global international waters assessment (GIWA), SubRegional Report, Somali current, Sub-Region, No. 46.

Shaghude, Y.W. 2001. Shallow water carbonate basin of the Zanzibar channel, Tanzania. PhD Thesis, Dept of Geology and Geochemistry, Stockholm University.

Shaghude, Y.W., Mutakyahwa, M.K.D. and Mohammed, S.K. 1994. National report on the status of coastal erosion, sea level changes and their impacts, Tanzanian case. Proceedings of the IOC-UNEP-WMO-SAREC Workshop on Integrated approach to coastal erosion, sea level changes and their impacts. Intergovernmental Oceanographic Commision, Workshop report No. 96, Supplement 1: 85-106.

Shaghude, Y.W. and Wannäs, K.O. 1998. Morphology and sediment distribution of the Zanzibar channel. Ambio, 27(8): 729-733.

Shaghude, Y.W. and Wannäs, K.O. (2000). Mineralogical and biogenic composition of Zanzibar channel sediments, Tanzania. Journal of Estuarine, Coastal and Shelf Sciences, 51: 477-489. 
Shaghude, Y.W., Wannäs, K.O. and Mahongo, S.B. 2002. Biogenic Assemblage and Hydrodynamic Setting of the Tidally Dominated Reef Platform Sediments of the Zanzibar Channel. Western Indian Ocean Journal of Marine Sciences, 1(2): 107-116.

Shaghude, Y.W., Nyandwi, N., Muzuka, A.N.N., Dubi, A. M. and Mwaipopo, O.U. (2003). Sediments characteristics and hydrodynamic settings of reef platform sediments of Kunduchi, north of Dar es Salaam harbour. Presented during the third WIOMSA Scientific symposium, 15-18 October 2003, Maputo Mozambique.

Stockley, G.M. 1928. The Geology of Zanzibar and Pemba Islands, 44p., Zanzibar: Zanzibar museum.

Wagner, G.M. 1999. Coral reefs: Importance, threats, conservation and restoration, In: K.M. Howell and A. K. Semesi (editors), Coastal resources of Bagamoyo district, Tanzania. Proceedings of a Workshop on Coastal Resources of Bagamoyo, 18-19 December 1997, Faculty of Science, University of Dar es Salaam, Tanzania, pp. 27-32.

World Bank 1997. Tanzania: Water sector study, Water, Urban and Energy 1, Eastern and Southern Africa, Africa Region. 


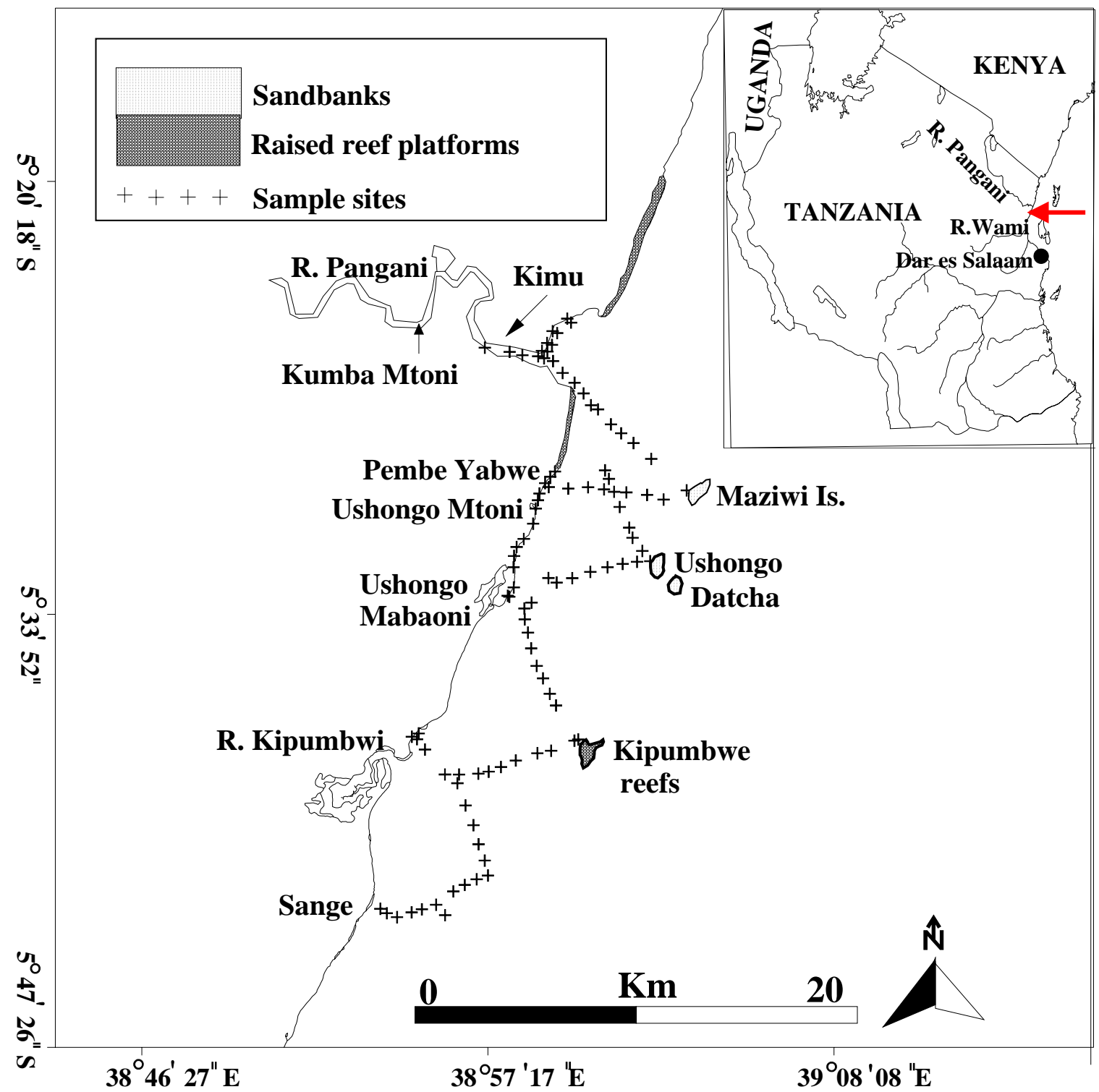

Fig. 1. Map showing the investigated shore of the Tanzania mainland, south of Pangani River. The crosses on the map represent sediment sampling locations. 


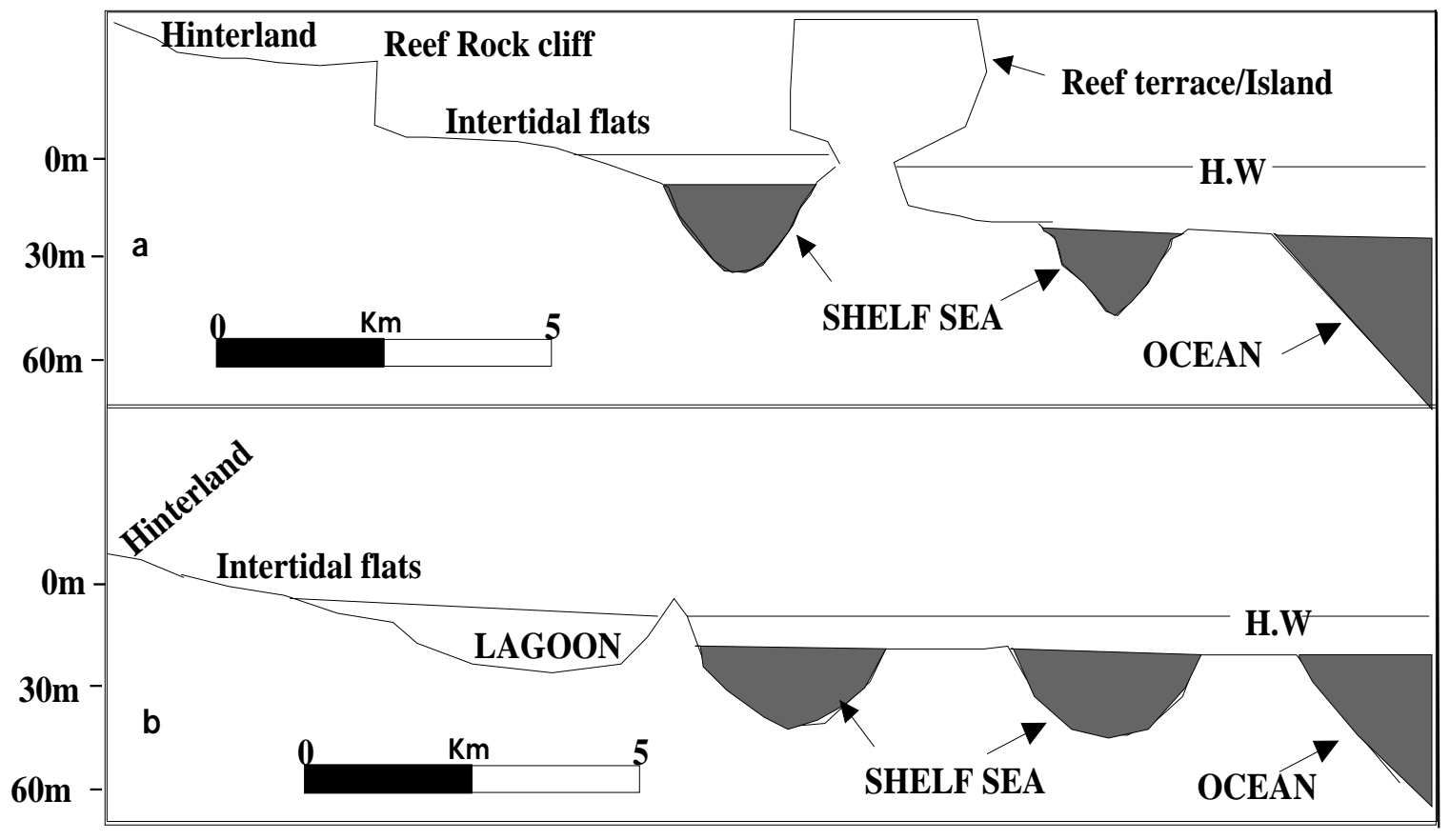

Fig. 2. Comparative shore-normal sections showing the two patch reef coastal types $(\mathrm{a}=$ Patch reef coast with fossil reef terrace/Islands and $b=$ patch reef coast with sand spit shore), characterizing the coastal section between River Pangani and Kipumbwi. The classification scheme is adapted from Kuria and Nyandwi (2000). 


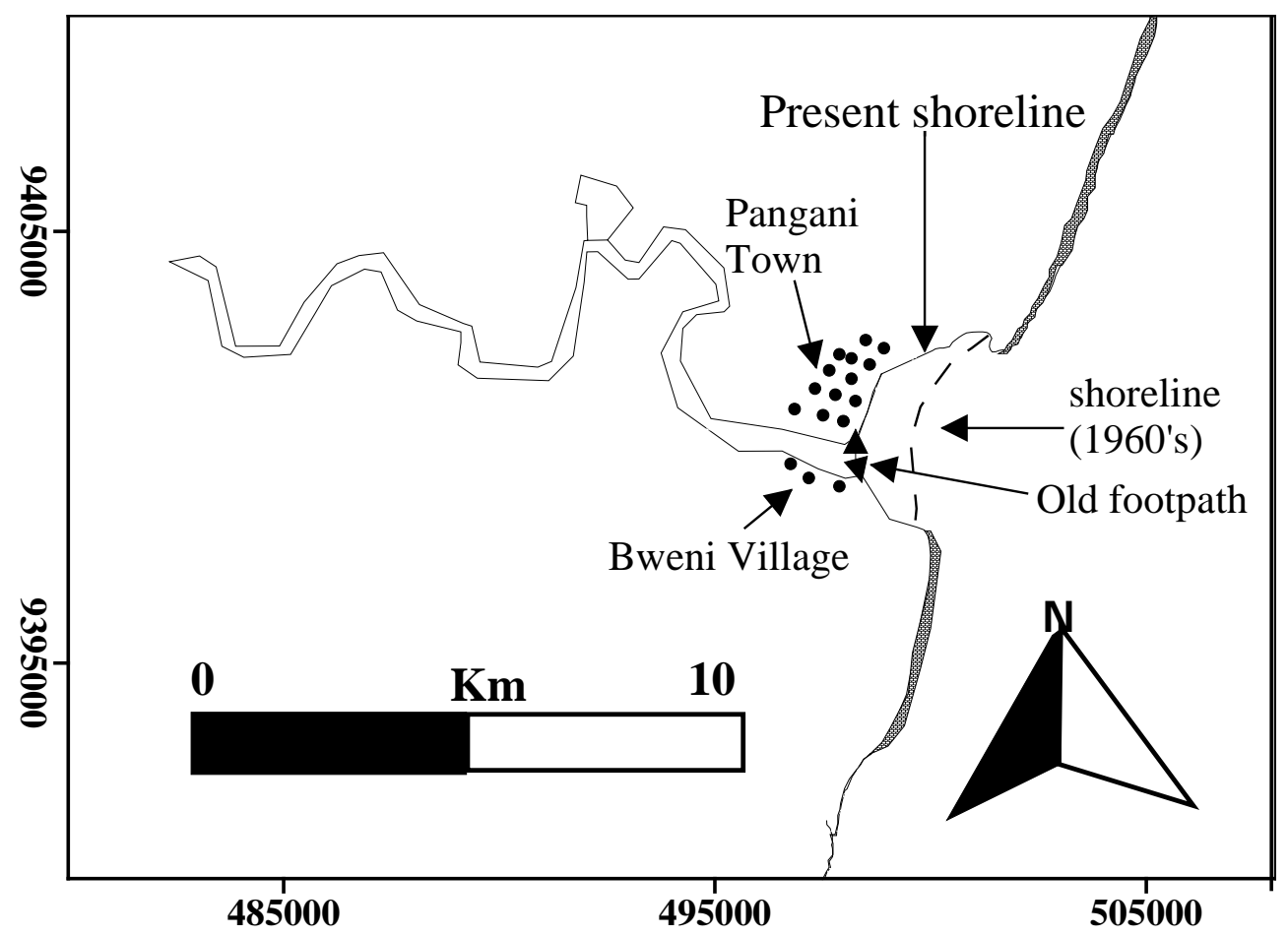

Fig. 3. Map showing the Pangani river estuary, the Pangani town and the eroding coastal section north of the river mouth. 


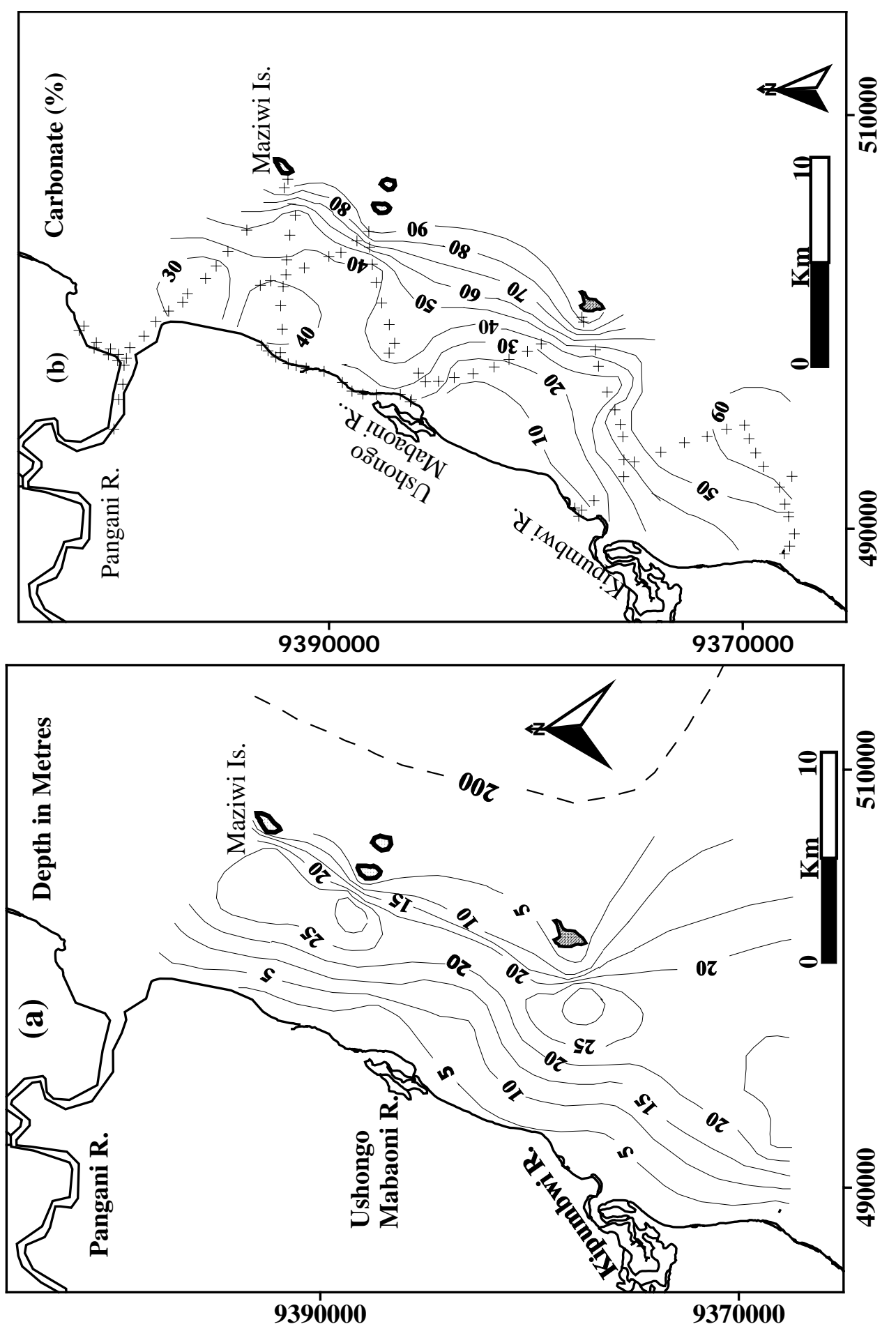

Fig. 4. Map showing the nearshore bathymetry (a) and the distribution of carbonate content in the sediments (b). 

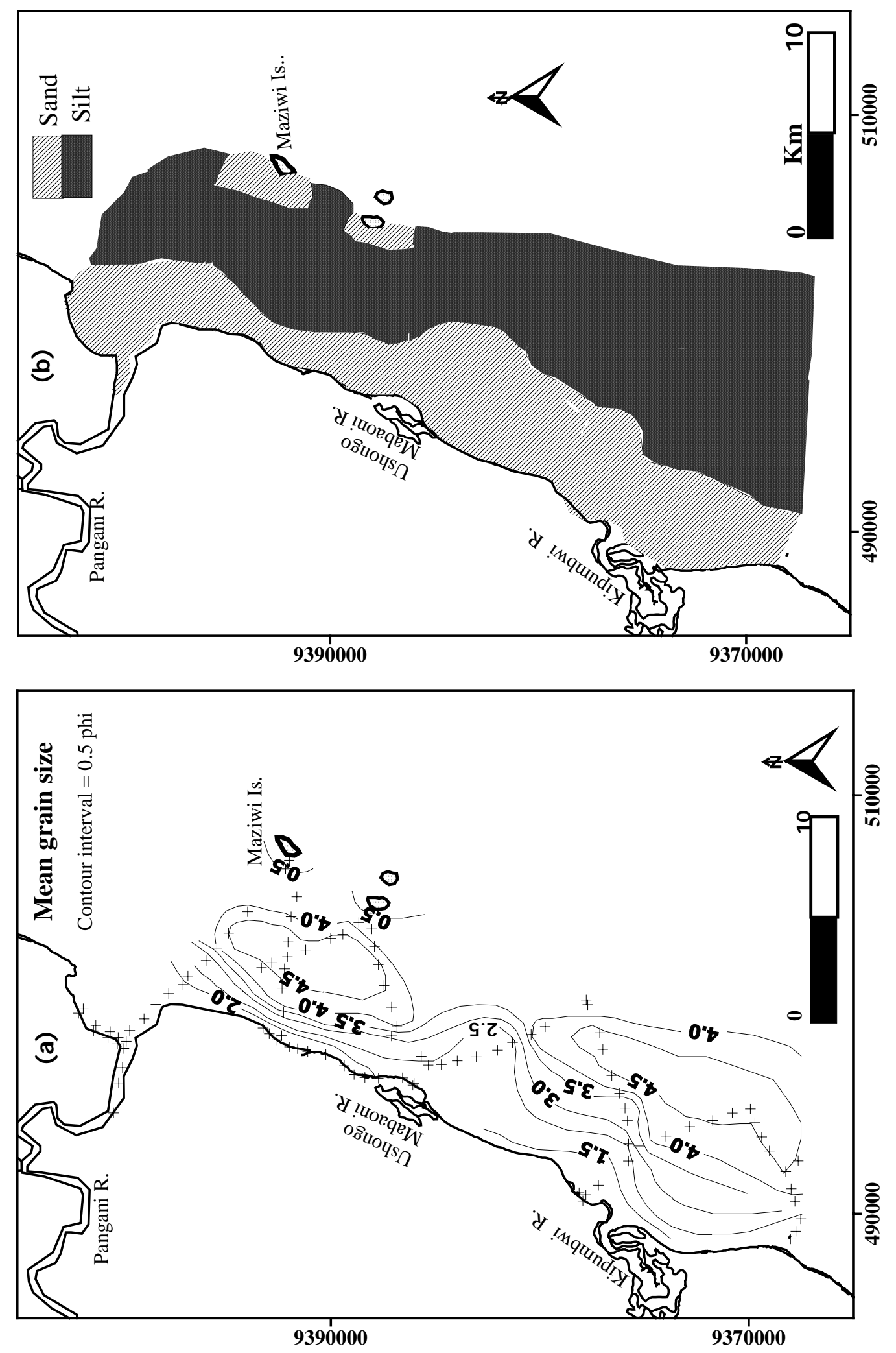

Fig.5. Map showing the distribution of sand and silt sediment classes on the sea bottom (a) and the more detailed mean grain size distribution (b). 


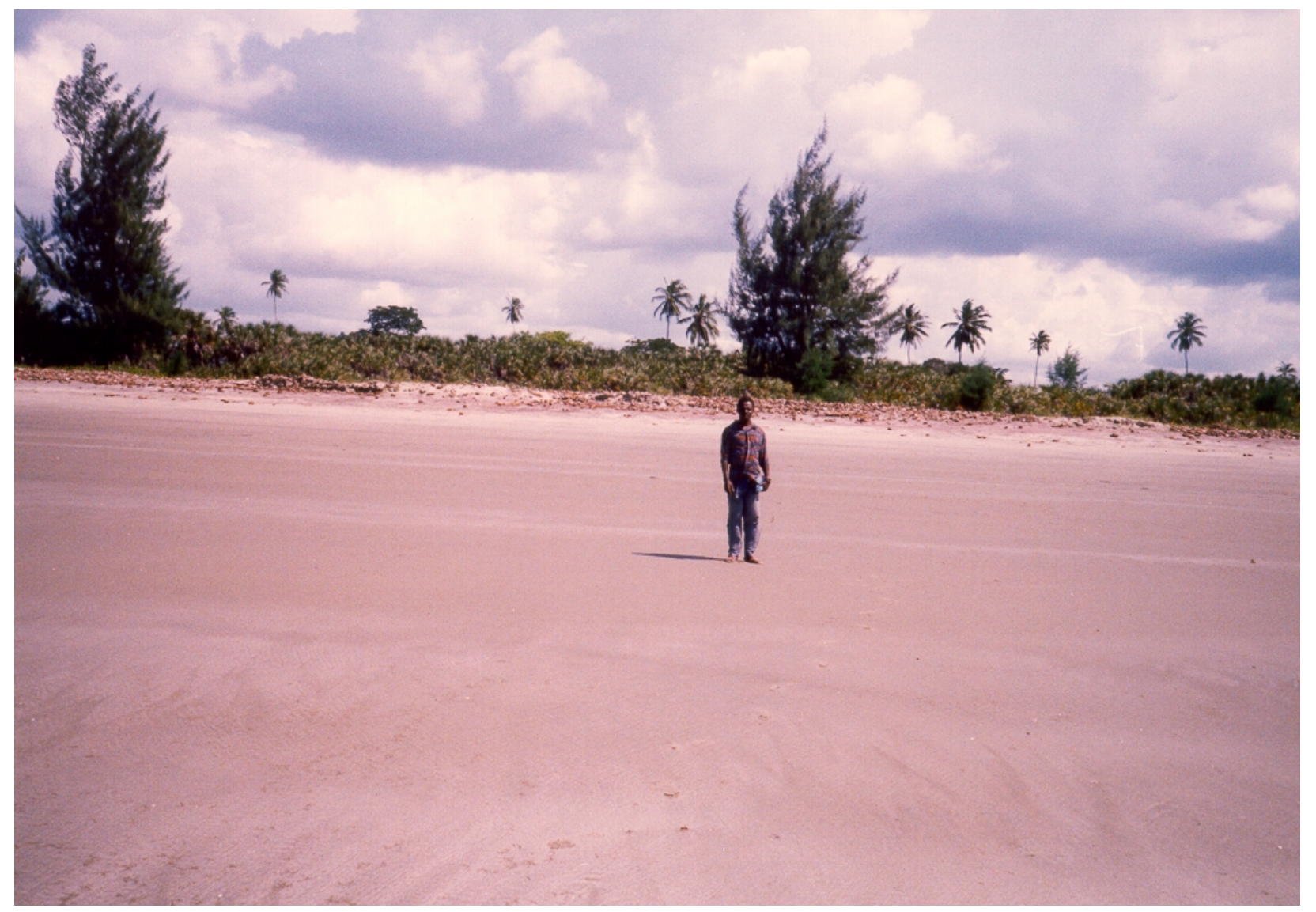

Plate 1. Beach head erosion north of Pangani river mouth. Observe that the tyre groynes (believed to be submerged) were placed in front of the person visible in the image, and the shore has retreated $30 \mathrm{~m}$ further inland. 